\title{
Analysing EU Sectoral Trade Integration with Gravity Model of Trade
}

\author{
Ildiko Virag-Neumann \\ MTA-PE (Hungarian Academy of Sciences-University of Pannonia) Networked \\ Research Group on Regional Innovation and Development Studies, Hungary \\ University of Pannonia, Faculty of Economics, Department of International \\ Economics, Hungary
}

\begin{abstract}
The objective of this research is provide an overview of EU integration effects on international trade and sectoral trade integration as reported by a relevant gravity model and fixed effect panel estimation. In order to evaluate the EU economic integration effects across sectors, I build up a sectoral gravity model. Gravity model based studies have achieved empirical success in explaining various types of flows, including migration, commuting, goods, money capital information and international trade. Trade within Europe is still impeded by significant barriers. In particular, there remain many non-tariff barriers, including so-called TBT "Technical Barriers to Trade". (Theie, 2014) These barriers result from regulations by requiring specific product characteristics or production processes. (Chen and Novy 2011) The sectoral trade integration analysis is deepened with capturing TBT coefficient compiled for separate sectors. The aim of this paper is to explore the implicit trade obstacles or barriers that still exist among EU members and to prove the trade-reducing effect of such remaining obstacles in separate sectors. My hypothesis is that different types of goods might face diverse entry barriers, and thus their gravity equation coefficients would differ across sectors.
\end{abstract}

Keywords: EU economic integration, gravity model of trade, panel estimation, economy, market

JEL classification: $052, \mathrm{~F} 15$

\section{Introduction}

This paper sets out to discuss how the gravity model is used to account for the presence of non-tariff barriers (NTBs) in trade, and how different applications have consequences for policy analysis.

The gravity model is a mathematical model based on analogy with Newton gravitational law which has been used to analyse spatial interaction between two or more points like the gravity in physics. (Paas, 2003) The model is convenient as an examination tool for many reasons such as simplicity, high explanatory ability and improved econometrics. (Wall, and Cheng, 1999) The gravity model of international trade was developed by Jan Tinbergen (1962). It is a multivariate linear regression model for modelling bilateral and regional trade used for analyzing cross section and panel data. In order to evaluate the EU economic integration effects across sectors, I build up a sectoral gravity model which allows us to capture the implicit benefits of EU trade. According to the value of the distance coefficients I try to prove with fixed effect panel estimation in which sectors or industries is the trade integration greater compared to other industries.

The aim of this paper is to explore the trade obstacles or barriers that still exist 
among EU members and to prove the trade-reducing effect of such remaining obstacles in separate sectors. My working hypothesis is that different types of goods might face diverse entry barriers, and thus their gravity equation coefficients would differ across sectors.

The paper is structured as follows. The first section is the introduction and presents the hypotheses that are tested at a later stage in order to answer the research question. The second section briefly reviews the different theoretical foundations of the gravity equation. After discussing the recent econometric developments in gravity modelling, the data collecting and database compiling procedure proposed. (Data, variables, specifications of the model)In order to evaluate the EU economic integration effects across sectors, I build up a sectorial fixed effect gravity model. In the final section the main results and consequences are summarized.

\section{Methodology}

\section{Theory of gravity model in international trade}

With its origins in Isaac Newton's law of gravity, the model posits that trade between two countries is directly proportional to the "gravitational" pull of their respective national incomes (GDP), and inversely proportional to the distance between them. Newton's law states that the attraction force between two bodies is directly related to their size and inversely related to the distance between them. (Paas, 2003, Pöyhonen, 1963)

The gravity model is an instrument which enables statistical analysis of flows and patterns with bilateral trade flow data. It predicts bilateral trade flows based on the economic sizes (often using GDP measurements) and distance between two units. The theoretical considerations are mostly based on microeconomic foundations, trade theories and new economic geography. The model is convenient as an examination tool for many reasons such as simplicity, high explanatory ability and improved econometrics. In this basic form of the gravity model, the amount of trade between two countries is assumed to be increasing in their sizes, as measured by their national incomes, and decreasing in the cost of transport between them, as measured the distance between their economic centres.

The gravity model of international trade was developed by Jan Tinbergen (1962). It is a multivariate linear regression model for modelling bilateral and regional trade used for analysing cross section and panel data. (Paas, 2003) The model posits that trade between two countries is directly proportional to the "gravitational" pull of their national incomes (GDP), and inversely proportional to the distance between them.

The gravity model has been used widely as a baseline model for estimating the impact of a variety of policy issues, including regional trading groups, currency unions, political blocks, various trade distortions and agreements, border region activities and also historical linkages." (Paas, 2003)

Several studies focus on examining the effects of regional trade agreements, currency unions and common markets as well as trade creating or diverting effects other researchers have examined trade policy implications and factors that affect trade, such as natural border effects, monetary union impacts, domino effects, the foreign direct investments, transportation costs. (Kepaptsoglou et al, 2010)'.

'The theoretical considerations for using gravity models to explore international trade flows have been widely discussed and developed. Anderson and van Wincoop (2004) propose an augmented version of the Anderson (1979) model based on the assumption of differentiation of goods according to place 
Bergstrand (1990) provided a foundation based on Dixit and Stieglitz's monopolistic competition assumption. ${ }^{2}$ Rauch (1999) estimates a disaggregated gravity model for three different types of goods: homogeneous, reference price, and differentiated and he confirms that adjacency and common links between countries are more important for differentiated products than for homogeneous goods. Rauch's results suggest that search barriers to trade are higher for differentiated than for homogeneous products. Feenstra, Markusen and Rose (2001) argue that gravity equations for differentiated and homogeneous goods differ empirically, given their varying degrees of specialisation. (Molinari, 2003)

\section{Methodology}

\section{Content of the model}

Thanks to various modelling refinements and their application to debates about theoretical foundation of the gravity equation, this model has established itself as a serious empirical tool for exploring regional trade patterns. (Paas, 2003) The regional integration effects as the deviations from the volume of trade predicted by the baseline gravity model, which expresses the impact of traditional gravitational forces like size of economy, population (Head, 2003), level of economic development and distance, are captured by dummy variables. ${ }^{3}$ Dummy variables are added to the gravity equation to capture features and differences between country pairs that can play a determining role in trade. Common dummy variables are language and borders which take consideration to cultural affinity and historical and economic ties between countries. They indicate lower transaction costs and possibly a more open market between countries.

But borders can also reflect a hinder to trade because crossing borders involves formalities that take time and tariff costs. In addition borders can indicate different languages and different currencies which hinder trade as well (Krugman and Obstfeld, 2006). Dummy variables can also capture for RTA effects.

Gravity models have been used extensively for the empirical analysis of a wide range of international economics topics, including FTAs. The multiplicative form of the gravity model (Anderson (1979), Bergstrand (1985, 1989), Anderson and van Wincoop (2003)) is the following:

of origin. (Gomez Herrera, 2011) Anderson (1979) derives a version of the gravity equation using trade costs and CES preferences and Bergstrand (1985) supported this. Helpman and Krugman (1985) also derived a foundation relying on the assumption of increasing returns to scale where products were differentiated by firms, not only by country, and firms were monopolistically competitive. (Gomez Herrera, 2011The exclusion of the multilateral trade resistance terms leads to biased estimates due to the omission of variables and this misspecification can invalidate the estimation.

2Another highly influential paper was McCallum (1995). He used the gravity equation to measure the effect of national borders on trade. He concludes that both national borders and bilateral distance are significant frictions to trade. This came at a time when the business press was claiming the "death of distance" and the "borderless world" as world trade became more integrated (Head and Mayer, 2014).

3The GDP variables in the gravity equation are used as representing the importer demand and exporter supply potential, which also indicates that the size of an economy has direct relation to the volume of imports and exports as indicated by the equation. Larger economies produce more goods and services which means they have more to sell in the export market. The coefficients have positive signs, because these are the traditional propulsion (for origins) and attraction (for destinations) variables in the gravity model. The sign and the statistical significance of these coefficients will indicate how these factors affect bilateral trade between a pair of countries. (Sargento, 2006) 


$$
\mathrm{FLOW}_{\mathrm{ij}}=\mathrm{AGDP}_{\mathrm{i}}^{\beta_{1}} \mathrm{GDP}_{\mathrm{j}}^{\beta_{2}} \mathrm{~d}_{\mathrm{ij}}^{\beta_{3}} \mathrm{~L}_{\mathrm{ij}} \mathrm{L}_{\mathrm{i}} \mathrm{L}_{\mathrm{j}} \varepsilon_{\mathrm{ij}}
$$

Taking logs of both sides leads to a log-log model of the form:

$$
\operatorname{lnFLOW}_{\mathrm{ij}}=\ln \mathrm{A}+\beta_{1} \operatorname{lnGDP} P_{\mathrm{i}}+\beta_{2} \operatorname{lnGDP} P_{\mathrm{j}}+\beta_{3} \operatorname{lnd}_{\mathrm{ij}}+\ln \mathrm{L}_{\mathrm{i}}+\ln \mathrm{L}_{\mathrm{j}}+\ln \mathrm{L}_{\mathrm{ij}}{ }^{4}
$$

The equation in log form can be estimated with linear regression techniques. Therefore, the model is actually a multivariate linear regression function, which is used for cross-sectional and panel data analysis. ${ }^{5}$

\section{Structure of gravity model, data source of the research}

Analyzing with gravity model, a database is required that integrates data describing country pairs and the countries. My sectorial export database is built with bilateral export data between the EU Member States in sectorial breakdown between 2009 to 2000 period. The sectorial export and production data are from OECD, STAN Database STA ISIC Rev. I have data for 25different sectors, the country and country pair data are from the OECD STAN database. Population and GDP data come from the World Bank Database (World Trade Indicators). Distance data are extracted from http://www. distancefromto.net//) ${ }^{6}$. The analysis was carried out with STATA 10 programme.

\section{Results}

The episode of EU enlargement serves as a reasonably good case for an experiment to study the effects of other trade barriers. According to the value of the distance coefficients I proved with fixed effect panel estimation that the trade integration in "high-tech" industries is greater compared to the homogenous goods and those with high shipping costs because of their higher distance coefficients.

The sectorial database was accomplished with TBT indicator. I have used two sources. The European Commission's Eurobarometer reports on opinions and experiences of European managers about the Single Market. (Chen and Novy, 2011) A total of 4,900 managers at companies were interviewed by telephone in early

\footnotetext{
4In which FLOW ij is the trade between economy $\mathrm{i}$ and $\mathrm{j}$ (as reported by economy $\mathrm{i}$ ); GDP $\mathrm{i}$ is GDP of economy $\mathrm{i}$, as a proxy for the size of the reporting economy; GDP $\mathrm{j}$ is GDP of economy j, as a proxy for the size of the partner economy; dij is the distance between $i$ and $j$, as a proxy of travel cost of trade(data are extracted from http://www.distancefromto.net/) Lij; Li, Lj, are the predictors, independent variables, stand for other variables such as common language and historical bonds, population, size of the economy; $\varepsilon_{\mathrm{ij}}$ is the residual of the regression;

5 It is criticised that cross-section estimation is miss-specified since it is not able to deal with bilateral heterogeneity and a panel based approach will be desired because heterogeneity can be modelled by including country-pair "individual" effects.(Serlenga-Shin,2004) Although a number of panel estimation techniques such as the pooled OLS, the Fixed Effects Model, the Random Effects Model have been applied in various papers, the Fixed Effects estimation has been the most preferred estimation method in order to avoid the biased estimation.

6The data matrix contains 7723 observations (rows) by industry (88 cells in a row). The matrix has 679,681 data cells by sector and regarding 25 sectors it is totally 193,075 observations that means a total of $4,826,875$ pieces of data cells (the 25 sector matrix data combined).
} 
2006, the sample of companies being selected according to the size of countries and of companies, and the industry of activity. ${ }^{7}$

To capture the sectorial relevance of TBTs, industries are classified at the NACE70 level on a five-point scale according to the effectiveness of different measures undertaken by the Single Market Programme to eliminate TBTs. My industry-specific qualitative variable takes on values between 1 and 5, with larger values indicating a lack of market integration due to persisting TBTs.

The sectorial trade integration analysis was deepened with capturing TBT ("Technical Barriers to Trade "coefficient compiled for separate sectors. The tradereducing effect of such remaining obstacles (TBT) in" Iron and steel" $(-13,08)$," Coke, refined petroleum products and nuclear fuel" $(-5,324)$, "Food and beverages" $(-8$, 72), "Electrical and optical equipment" $(-4,54)$ „Fabricated metal products" (-6.094) industries can be justified.

At the sector level, examples of industries where TBTs are successfully removed are "Dressing and dyeing of fur," "Electric domestic appliances," "Motor vehicles" or "Aircraft and spacecraft" while TBTs are still prevalent in "Jewellery" or "Imitation jewellery," among others. Given that TBTs require specific product characteristics or production processes we would expect them to be stronger for differentiated than for homogeneous goods.

The trade integration is low in the following sectors: (distance parameter) "Coke, Refined Petroleum products and nuclear fuel" (-2.060) "Extraction of crude petroleum and natural gas and related services" (-1.827) and" Non ferros" sector. These sectors can be characterised with high transport costs.

The trade integration is low in "Agriculture, Hunting, Forestry and Fishing" (-1.163), „Mining and Quarrying" (-1.466), and in „Food products" $(-1,106)$. In sectors which are well integrated including some "high-tech" industries, like" Machinery and equipment" $(-0,646)$ "Accounting and Computing Machinery „(-0.496),"Electrical machinery and apparatus" $(-0,353), " R a d i o, ~ T e l e v i s i o n$ and communication equipment" $(-0,208)$ the distance coefficients are lower.

TBT coefficient is computed according to country specific (TBTi; TBTj) and sector specific (TBTt) characteristics in CES formation is often used in the literature of international trade:

$T B T_{i j t}=\left[T B T_{i}^{1 / 2}+T B T_{j}^{1 / 2}+T B T_{\dagger}^{1 / 2}\right]^{2}$

\footnotetext{
7l use the answer to the question: "Could you tell me whether you consider that for your company it is very important, rather important, rather unimportant or not important at all that future single Market Policy tackles the question of removing remaining technical barriers to trade in goods?" For each country, I grouped the answers from all managers who replied that TBTs are indeed an important issue, and use the percentage so obtained as a country-specific indication on the relevance of TBTs.
} 


\section{Table 1}

Three dimensional panel data analysis distance, TBT coefficients 2000-2009

\begin{tabular}{|c|c|c|c|}
\hline Sector(Industry) & $\begin{array}{l}\text { Distance } \\
\text { parameter } \\
\text { estimated }\end{array}$ & $\mathrm{R}^{2}$ & $\begin{array}{c}\text { TBT } \\
\text { coefficient }\end{array}$ \\
\hline $\begin{array}{l}\text { C11 Extraction of crude petroleum and } \\
\text { natural gas and related services }\end{array}$ & -2.677 & 0,889 & $-11,741$ \\
\hline $\begin{array}{l}\text { C15Food products, Beverages and } \\
\text { Tobacco }\end{array}$ & $-0,727$ & 0,905 & $-8,720$ \\
\hline C17T19 Textiles, Textile Products & $-0,403$ & 0,811 & -6.986 \\
\hline $\begin{array}{l}\text { C20T22 Wood and Products of Wood and } \\
\text { Cork }\end{array}$ & $-1,289$ & 0,789 & 0,557 \\
\hline C21 Pulp, Paper, Paper Products, & $-0,001$ & 0,390 & $-9,343$ \\
\hline $\begin{array}{l}\text { C23Coke, Refined Petroleum Products and } \\
\text { Nuclear Fuel }\end{array}$ & $-1,478$ & 0,789 & 3,234 \\
\hline $\begin{array}{l}\text { C23T25 Chemical, Rubber, Plastics and Fuel } \\
\text { Products }\end{array}$ & $-0,624$ & 0,721 & 2,630 \\
\hline C24 Chemicals and Chemical Products & -0.734 & 0.9194 & 3.293 \\
\hline C25 Rubber and Plastics Products & -0.52741 & 0.8781 & -4.251753 \\
\hline $\begin{array}{l}\text { C26Other Non-Metallic Mineral Products } \\
\text { C27 Basic Metals }\end{array}$ & $\begin{array}{l}-0.75543 \\
-0.604\end{array}$ & $\begin{array}{l}0.8734 \\
0.7358\end{array}$ & $\begin{array}{l}2.83725 \\
-1.592129\end{array}$ \\
\hline $\begin{array}{l}\text { C27T28 Basic Metals and Fabricated Metal } \\
\text { Products }\end{array}$ & -0.61821 & 0.9232 & -2.253819 \\
\hline C28 Fabricated Metal Products & $-0,571$ & 0.9226 & -6.094 \\
\hline C27T31 Iron and Steel & -0.8065 & 0.9186 & -13.08783 \\
\hline $\begin{array}{l}\text { C30 Electrical and Optical Equipment, } \\
\text { office, accounting and computing } \\
\text { machinery }\end{array}$ & $-0,434$ & 0,890 & 2,160 \\
\hline C29T31 Machinery and Equipment & $-0,600$ & 0,512 & 0,090 \\
\hline C272 Non-ferrous metals & $-1,423$ & 0,772 & $-0,102$ \\
\hline $\begin{array}{l}\text { C31Electrical machinery and apparatus, } \\
\text { n.e.c }\end{array}$ & $-0,456$ & 0,902 & $-5,388$ \\
\hline $\begin{array}{l}\text { C33 Medical, precision and optical } \\
\text { instruments }\end{array}$ & $-0,379$ & 0,927 & $-4,492$ \\
\hline C30T33 Electrical and Optical Equipment & $-0,499$ & 0,878 & $-7,54$ \\
\hline $\begin{array}{l}\text { C34 Motor vehicles, trailers and semi- } \\
\text { trailers }\end{array}$ & $-0,393$ & 0,906 & $-0,57$ \\
\hline C34T35 Transport Equipment & $-0,708$ & 0,867 & $-0,003$ \\
\hline $\begin{array}{l}\text { C352 Railroad equipment and transport } \\
\text { equipment n.e.c. }\end{array}$ & $-0,527$ & 0,817 & 1,390 \\
\hline
\end{tabular}

Source: figures are based on own calculation

TBT coefficient is high in sector" Iron and steel" $(-13,08), "$ Coke, Refined Petroleum products and nuclear fuel" $(-5,324)$, "Food and beverages" $(-8,72)$, "Electrical and optical equipment" (-4, 54) „Fabricated metal products" (-6.094) industries. According to the sectorial gravity estimation in these sectors the trade integration is impeded by technical barriers to trade. 
Figure 1

Regression shape textile sector
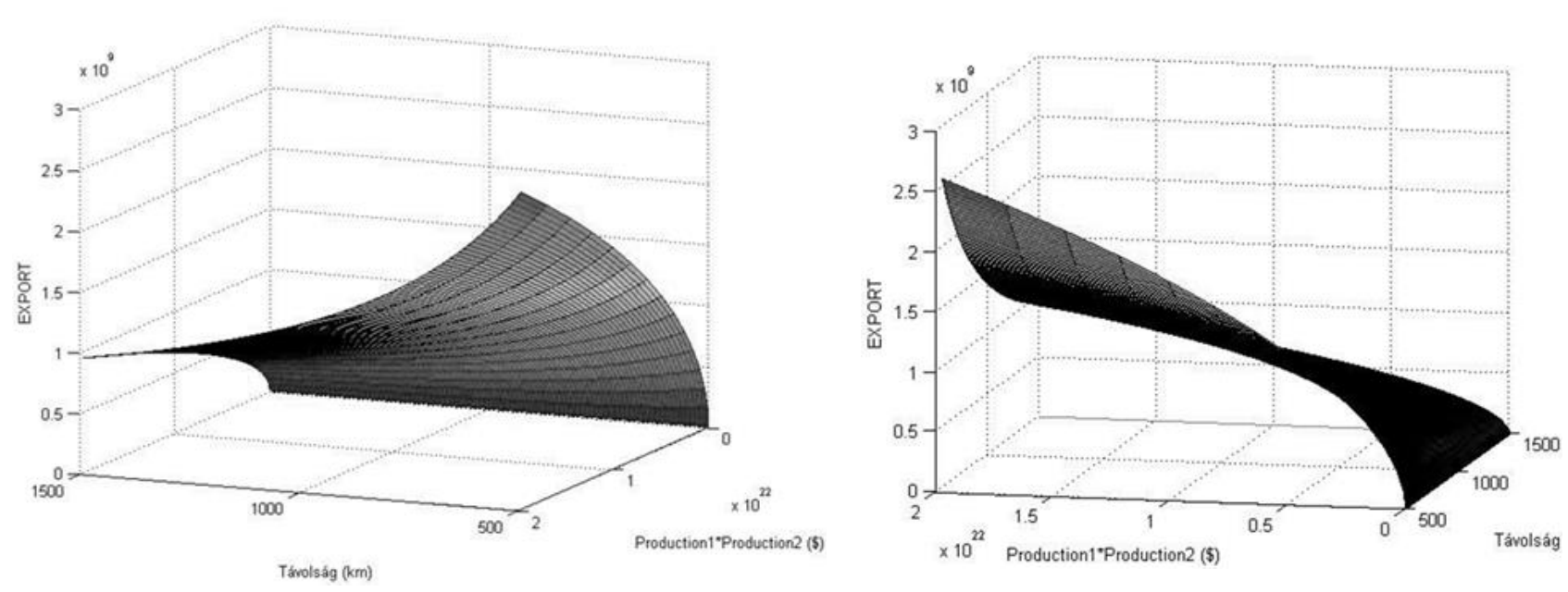

Source: figures are based on own calculation with Matlab programme

\section{Conclusion}

Most of the beneficial effects of EU enlargement are hard to quantify: institutional stability and modernization, economic growth etc. How much of the positive domestic changes are due to promises of EU accession and how much would have happened on their own? Most of these effects manifested slowly over a decade and a half. There is one area, though, where the gains are more palpable: trade liberalisation. I have estimated the level and trends of sectoral integration effects between EU members, in order to assess both the level and the evolution of EU trade integration.

I apply robust standard errors in my estimations. In aim of receiving the best regression results from the OLS an alternative version of the standard gravity equation, a fixed effect equation is calculated and run as well. I have to take into consideration a correct specification of multilateral resistance terms in a panel data set. Although this research was carefully prepared, I am still aware of its limitations. First of all, the research was conducted between 2000-2009, for further research, the present study can be extended by using a more complete data set after 2009.A longer period will likely lead to interesting results.

\section{References}

1. Anderson, J. (2010) "The Gravity Model", NBER Working Paper 16576

2. Anderson, J., van Wincoop, E. (2004) "Trade Cost", Journal of Economic Literature, Vol. 42

3. Anderson, J., van Wincoop, E. (2002) "Borders, Trade, and Welfare", in: Collins, S.M., Rodrik, D. (Eds.), Brookings Trade Forum, Brookings Institution, 207-244. p.

4. Anderson, J., van Wincoop, E. (2003) "Gravity with Gravitas: A Solution to the Border Puzzle", American Economic Review, March (2003) 93, 170-192. p.

5. Baldwin, R.E., Taglioni, D. (2006) "Gravity for Dummies and Dummies for Gravity Equations", NBER Working Paper 12516. 
6. Bergstrand, J. H. (1985) "The Gravity Equation in International Trade: Some Microeconomic Foundations and Empirical Evidence", Review of Economics and Statistics (1985), 67 (3), pp. 474-481

7. Chen, N., Novy, D. (2011) "Gravity, trade integration, and heterogeneity across industries Journal of international economics". Amsterdam Elsevier, ISSN 0022-1996, ZDB-ID 1201438. - Vol. 85.2011, 2, pp. 206-221

8. European Commission (2006) "Internal Market: Opinions and Experiences of Businesses in EU-15". Flash Eurobarometer 180, TNS Sofres/EOS Gallup Europe

9. Feenstra, R.C., Markusen, J.R., Rose, A.K. (2001) "Using the gravity equation to differentiate among alternative theories of trade", available at: http://onlinelibrary.wiley.com/doi/10.1111/0008-4085.00082/abstract (7/5/2016)

10. Gujarati, D. N. (2003) "Basic Econometrics", The McGraw-Hill Companies, p.1002.

11. Head, K. (2003) "Gravity for Beginners", University of British Columbia, available at: strategy.sauder.ubc.ca/head//gravity.pdf (5/5/2016)

12. Herrera G. (2011) "Comparing alternative methods to estimate gravity models of bilateral trade". ETSG Conference Proceedings

13. OECD STAN Database for Structural Analysis (ISIC Rev. 3)-OECD.Stat available at: http://www.oecd.org/industry/ind/stanstructuralanalysisdatabase.htm (3/5/2016)

14. Molinari, A. (2003) "Sectoral Border Effects: Analysing Implicit EU Trade Integration" available at: http://www.etsg.org/ETSG2003/papers/molinari.pdf (1/5/2016)

15. Paas, T. (2003) "Regional integration and international trade in the context of EU eastward enlargement". HWWA Discussion Paper, pp. 218.

16. Pöyhonen, P. (1963) "A Tentative Model for the Volume of Trade between Countries", Weltwirtschaftliches Archiv, 90 (1), pp. 93-99.

17. Sargento, A.L.M. (2006) "Empirical examination of the gravity model in two different contexts: estimation and explanation". International Conference on Regional and Urban Modelling, Brussels, June 1-3, 2006

18. Serlenga, L., Shin, Y. (2004) "Gravity models of the intra-EU trade: application of the Hausman-Taylor estimation in heterogeneous panels with common time-specific factors". ESE Discussion Papers, No. 105.

19. Theie, M.M.G. (2014) "Non-tariff barriers, trade integration and the gravity model", Master thesis,

available

at: https://www.duo.vio.no/bitstream/handle/10852/40976/Theie-MarcusGjems.pdf? sequence=1 (6/5/2016)

20. Tinbergen, J. (1962) "Shaping the World Economy: Suggestions for and International Economic Policy", New York: the Twentieth Century Fund

21. Wall, H.J., Cheng, I.H. (1999) "Controlling for heterogeneity in gravity models of trade", Working Paper 99-010A, available at: http://spol.unica.it/didattica/ampinna/Modelli\%20di\%20integrazione\%20economic a/Heterogeneity\%20in\%20Gravity.pdf (3/5/2016)

22. World Bank, "World Bank Indicators", available at: http://data.worldbank.org/indicator (1/5/2016)

\section{About the author}

Ildiko Virag-Neumann, Ph.D. works in MTA-PE (Hungarian Academy of SciencesUniversity of Pannonia) Networked Research Group on Regional Innovation and Development Studies, Hungary and in Department of International Economics Institute of Economics Faculty of Economic Sciences in University of Pannonia Veszprém, Hungary. Research fields are: International Economics, international trade, European integration, EU enlargement to Central and Eastern Europe. Author can be contacted at ildiviragvirag@gmail.com. 